\title{
Biochemical changes throughout early- and middle-stages of embryogenesis in lobsters (Homarus americanus) under different thermal regimes
}

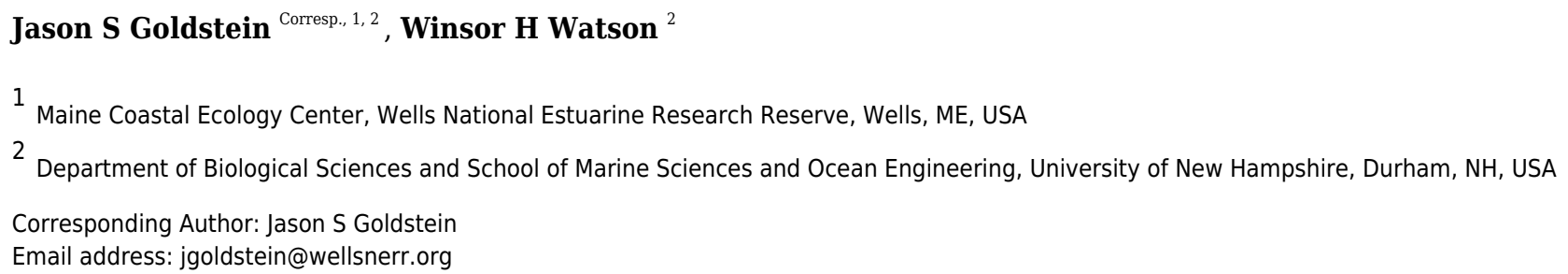

Most marine crustacean eggs contain the full complement of nutritional resources required to fuel their growth and development. Given the propensity of many ovigerous (eggbearing) American lobsters (Homarus americanus) to undergo seasonal inshore-to-offshore migrations, thereby potentially exposing their eggs to varying thermal regimes, the goal of this study was to determine the impact of water temperature on egg quality over their course of development. This was accomplished by documenting changes in total lipids, proteins, and size (volume) of eggs subjected to one of three thermal regimes: inshore, offshore, and constant $\left(16^{\circ} \mathrm{C}\right)$. Total egg lipids showed a marked decrease over time, while protein levels increased over the same period. Although there were no significant differences in total lipids, proteins, or egg sizes between eggs exposed to inshore and offshore temperatures, they differed from values for eggs exposed to a constant temperature, which also hatched almost three months sooner. This is most likely due to the fact that eggs held at a constant temperature did not experience a period of slow development during the colder months from November to March that are important for synchronizing egg hatch and may be compromised by elevated seawater temperatures. 
1

3 (Homarus americanus) under different thermal regimes

4

5

6

7

8

9

Jason S. Goldstein ${ }^{1,2^{*}}$ and Winsor H. Watson ${ }^{2}$

${ }^{1}$ The Maine Coastal Ecology Center, Wells National Estuarine Research Reserve, 342 Laudholm Farm Road, Wells, ME, 04090 USA. <jgoldstein@wellsnerr.org>

${ }^{2}$ Department of Biological Sciences and School of Marine Sciences and Ocean Engineering, University of New Hampshire, 46 College Road, Durham, NH 03824 USA.

\section{Biochemical changes throughout early- and middle-stages of embryogenesis in lobsters}

\author{
Farm Road, Wells, ME, 04090 USA. <jgoldstein@wellsnerr.org
} (1) University of New Hampshire, 46 College Road, Durham, NH 03824 USA.

(1)




\section{ABSTRACT}

35

36 Most marine crustacean eggs contain the full complement of nutritional resources required to

37 fuel their growth and development. Given the propensity of many ovigerous (egg-bearing)

38 American lobsters (Homarus americanus) to undergo seasonal inshore-to-offshore migrations,

39 thereby potentially exposing their eggs to varying thermal regimes, the goal of this study was to

40 determine the impact of water temperature on egg quality over their course of development. This

41 was accomplished by documenting changes in total lipids, proteins, and size (volume) of eggs

42 subjected to one of three thermal regimes: inshore, offshore, and constant $\left(16^{\circ} \mathrm{C}\right)$. Total egg

43 lipids showed a marked decrease over time, while protein levels increased over the same period.

44 Although there were no significant differences in total lipids, proteins, or egg sizes between eggs

45 exposed to inshore and offshore temperatures, they differed from values for eggs exposed to a

46 constant temperature, which also hatched almost three months sooner. This is most likely due to

47 the fact that eggs held at a constant temperature did not experience a period of slow development

48 during the colder months from November to March that are important for synchronizing egg

49 hatch and may be compromised by elevated seawater temperatures. 
51

52

53

54

55

56

57

58

59

60

61

62

63

64

65

66

67

68

69

70

71

72

73

74

75

\section{INTRODUCTION}

Egg development for most marine crustaceans relies heavily on the production and sequestering of nutrients required for the entire process of embryogenesis. In terms of biochemical constituents, both lipids and proteins play pivotal roles throughout development, and as a result, have been studied extensively in crustaceans and fishes (Fraser, 1989; Jaeckle, 1995; Rosa, Calado, Narcisco \& Nunes, 2007). Lipids comprise the structural integrity of most cells and are required for much of the metabolism of crustacean embryos, accounting for upwards of $60 \%$ of the total energy expenditure for growth (Holland, 1978; Amsler \& George, 1984). By contrast, proteins constitute the basic building blocks of animal tissues (Holland, 1978), and may also function as alternative energy sources under certain conditions (Schmidt-Nielsen, 1991; Heras, Gonzales-Baro \& Pollero, 2000).

Egg development in crustaceans is also very sensitive to thermal conditions, and incubation periods can be extended by cold water temperatures, or reduced during warmer conditions, thus influencing timing to hatch (reviewed in Giménez, 2006). Furthermore, as metabolic rates increase at higher temperatures nutrients are used up at a faster rate and this can influence egg survival (Pandian, 1970; Schmidt-Nielsen, 1991). Because most marine species larvae derive their nutrition from both exogenous (feeding) and endogenous (yolk reserves) sources (Sasaki, McDowell Capuzzo \& Biesiot, 1986), this can also have an impact on their development and metamorphosis. Therefore, the relationship between the primary biochemical components in crustacean eggs and their associated thermal variability are considered central to the early-life history patterns for these organisms (Vance, 1973; Jaeckle, 1995). 
American lobsters, Homarus americanus H. Milne-Edwards (1837) are large, highly mobile, decapods whose habitats include coastal and continental shelf waters, bays, and estuaries from Labrador, Canada to Cape Hatteras, U.S. (Fogarty, 1995). Lobster eggs are typically extruded and fertilized in the late summer and fall, and then carried on the underside of the female's abdomen for 9-11 months before they hatch the following spring/summer. During this time, they are exposed to seasonal fluctuations in water temperature that can have a pronounced impact on their development (Perkins, 1972; Goldstein \& Watson, 2015a). Moreover, many ovigerous females undertake inshore-to-offshore seasonal migrations that can either enhance, or reduce, the magnitude of the seasonal temperature fluctuations their eggs experience (Campbell \& Stasko, 1986; Cowan, Watson, Solow \& Mountcastle, 2007; Goldstein \& Watson, 2015a). For example, ovigerous lobsters subjected to inshore thermal regimes in laboratory-based studies exhibited more rapid egg development and hatched sooner than their offshore counterparts (Goldstein \& Watson, 2015b). This was most likely due to the rapid warming of the inshore waters in the spring, because the mean temperatures in the two locations were not significantly different. Therefore, Goldstein and Watson (2015a) concluded that the seasonal offshore movements of ovigerous lobsters was most likely a strategy to enhance the survival of larvae, rather than a mechanism to speed up or delay egg development.

Although optimal temperatures for lobster egg growth are not fully known, naturally fluctuating temperatures result in disparate growth patterns and subsequently, differing hatch times (Sibert, Ouellet \& Brethes, 2004; Goldstein \& Watson, 2015b). In general, either prolonged warm or cold temperatures can have a deleterious effect on the utilization of egg yolk reserves (GarciaGuerrero, Racotta \& Villareal, 2003; Manush, Pal, Das \& Mukherjee, 2006), and it has been 
99 suggested that prolonged cold temperatures $\left(<4^{\circ} \mathrm{C}\right)$ negatively affect egg development in $H$.

100

101

102

103

104

105

106

107

108

109

110

111

112

113

114

115

116

117

118

119

120

121 americanus (Waddy \& Aiken, 1995).

The goal of this study was to determine the effects of temperature on the protein and lipid reserves of Homarus americanus eggs. Given the tendency for lobsters along the southern Maine coastline to migrate offshore in the winter, we hypothesized that this behavior might expose them to a thermal regime that maximized their metabolic efficiency, allowing for both optimal growth and maintenance of energy reserves in the form of stored lipids. To test this hypothesis, we held females carrying fertilized eggs under different thermal regimes and monitored changes in total lipids, proteins, and egg size during the course of their development.

\section{METHODS}

\section{Lobster source and egg assessment}

A total of 15 egg-bearing (ovigerous) lobsters were legally collected (New Hampshire Fish \& Game permit, RSA 214:29) in late August and early September (2006) along the New Hampshire (NH) seacoast near Rye, NH and Gunboat Shoals (43‥0274 N; $70^{\circ} .6938 \mathrm{~W}$, southern Gulf of Maine) by permitted commercial lobstermen using standard baited traps. Lobsters were transported to the University of New Hampshire (UNH) Coastal Marine Laboratory in Newcastle, NH and lobsters were initially held in a large 1,200 L fiberglass tank with shelters. The holding tank was sourced by ambient sand-filtered seawater (average temp $=15.3 \pm 0.5^{\circ} \mathrm{C}$ ) and was subjected to ambient light. Lobsters in the tank were fed a combination of fresh squid and crabs (Cancer spp.), twice per week. 
122 Lobster carapace lengths (CL) were measured to the nearest $1 \mathrm{~mm}$ using digital calipers

123 (Mitutoyo IP 65, Mitutoyo Corp., Japan) (size range: 84-96 mm CL) and a laminated disc tag

124 (diameter $=2.0 \mathrm{~cm}$, Floy Tag Inc., Seattle, WA) was fastened to the propus of each animal with a

125 single ziptie for identification throughout the duration of the study. A subset of eggs from each

126 lobster clutch $(n=15-20)$ were viewed under a dissecting scope on September-5 and staged

127 according to the methods outlined by Helluy \& Beltz (1991). Only lobsters whose clutches had

128 eye indices $<18 \%$ (Perkins, 1972; Goldstein \& Watson, 2015b) were used for this sample to

129 encompass as much of the early development process as possible (Perkins, 1972).

130

131 Thermal treatments and sampling

132 The experimental setup and thermal treatments are described in detail in Goldstein and Watson

133 (2015b). Briefly, six $0.91 \mathrm{~m}$ diameter $(600 \mathrm{~L})$ tanks (2 tanks/ treatment) were used to simulate

134 either inshore, offshore, or constant $\left(16 \pm 0.4^{\circ} \mathrm{C}\right)$ temperature regimes on a year-round basis.

135 Lobsters in each tank were kept isolated using mesh dividers and each animal received a shelter

136 and was exposed to ambient photoperiod. For purposes of this study thermal regimes were

137 simulated to either match inshore locations (shallow and coastal, 2-5 km from shore, 8-10 m

138 depth) or the offshore habitats (12-20 km from shore, 20-30 $\mathrm{m}$ depth) to which lobster migrate in

139 the fall and overwinter (see Goldstein \& Watson, 2015b). Constant temperatures were chosen to

140 simulate a favorable (and predictable) growth temperature similar to eggs observed in Mackenzie

141 (1988). Temperatures in all tanks were logged every 30-minutes using HOBO pendant loggers

142 (model UA-002-64, Onset Computer, Bourne, MA) and later downloaded using Hoboware

143 software (HOBOware Pro v. 3.0). Inshore temperatures mirrored the ambient seawater that was

144 circulated through the CML seawater system while the temperatures in the offshore tanks were 
145 adjusted biweekly to simulate offshore temperatures based on historical and real time data 146 published on the Northeastern Regional Association of Coastal Ocean Observing Systems

147 website (NERACOOS, http://neracoos.org). A total of five ovigerous females were exposed to

148 each of the three temperature treatments and their eggs were sampled at five discrete time

149 periods: twice in the fall (Oct-15 \& Nov-15) during initial growth, once in the winter (Jan-15),

150 when eggs remain in a relative stasis, and twice in the spring (Mar-15 \& May-25), during periods

151 of rapid growth (Sibert, Ouellet \& Brethes, 2004; Goldstein \& Watson, 2015b).

152

153 Although in this study each lobster was not truly independently segregated, we chose this design

154 for two reasons: (1) as experimental replicates, lobster eggs are endowed with very thick-layered 155 egg casings that make them isolated from other eggs (with the exception of hatching events when 156 the chorion essentially ruptures, Talbot \& Helluy, 1995); and (2) logistically, we were not able to 157 isolate each lobster on 15 separate incoming seawater lines. This would have been especially 158 problematic for the offshore and constant seawater treatments where we were simulating these 159 conditions with temperature-controlled units. Instead, we created a reservoir tank where we 160 could very accurately control these conditions for each treatment more effectively. Therefore, we 161 attempted to minimize a lack of independence but are confident that keeping females isolated 162 within the same tanks was acceptable given the research question and associated analyses we 163 sought to explore.

165 At each sampling interval, lobster eggs ( 100/sample) were removed from the center of each 166 lobster clutch with a pair of fine forceps. All egg samples were rinsed and gently agitated with a $167 \quad 0.5 \%$ sodium hypochlorite and distilled water solution for $\sim 1 \mathrm{~min}$, , after which they were rinsed 
168 with $100 \%$ distilled water and blotted dry to remove the cement matrix holding the eggs together

169 (P. Talbot pers. comm.). Previous studies indicated that this chemical separation technique was

170 non-invasive and did not compromise the biochemical integrity of the eggs due to their complex

171 and thickened membranes (Johnson, Goldstein \& Watson, 2011). Each egg sample was divided

172 into 30 egg aliquots then freeze-dried at $-40^{\circ} \mathrm{C}$ for $24 \mathrm{hr}$. (Labconco Freeze Dryer 5, Kansas City,

$173 \mathrm{MO}$ ) and served as a stock for subsequent analyses. Samples were then ground down into a fine

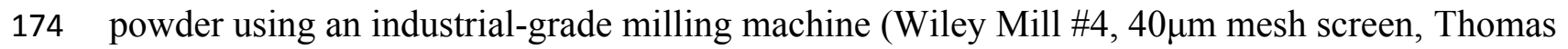

175 Scientific, Swedesboro, NJ) and samples were stored in labeled polyethelene scintillation storage

176 vials for subsequent analyses.

\section{Biochemical analyses}

179 For each of the five sampling intervals, we determined total lipids and proteins for each lobster 180 in triplicate ( $n=30 \times 3$ egg samples/female) using the methods described in Goldstein (2012). In 181 brief, total protein levels were determined using a modified Lowry method (Lowry, Rosebrough, 182 Lewis Farr \& Randall, 1951) using a BioRad protein assay kit with Coomassie Brilliant Blue G183250 (reagent standard) and bovine serum albumin as a standard (Biorad Laboratories, Hercules, $184 \mathrm{CA}$ ). Egg samples were digested in $1 \mathrm{~N} \mathrm{NaOH}$, filtered, and read on a spectrophotometer 185 (Beckman DU-250; $\lambda=595$ ). Total lipid was quantified gravimetrically using the general 186 protocol detailed in Bligh \& Dyer (1959). The procedure was modified to use a ratio of 1:2:2.5 187 chloroform-methanol-water extraction, respectively. Samples were dried for $24 \mathrm{hr}$ at $37^{\circ} \mathrm{C}$ and 188 stored in a glass dessicator, before being weighed on an analytic balance. 
191

192

193

194

195

196

197

198

199

200

201

202

203

204

205

206

207

208

209

210

211

212

213

\section{Egg volumes}

For calculating egg volumes, 10-15 fresh eggs were removed in the middle of each of four sampling months (Sep, Nov, Jan, and Feb) from each lobster and placed in plastic $2.0 \mathrm{~mL}$ storage tubes, preserved in a $4 \%$ formalin and sterile seawater solution and stored at $4^{\circ} \mathrm{C}$. Although we had intended to sample and calculate egg volumes in accordance with the same temporal sampling regimes as our biochemical assays, for logistical reasons we were not able to do so. For each egg, a digital picture was taken using a Nikon Coolpix 995 digital camera mounted to a dissecting microsope (Nikon SMZ-2T, Nikon USA Inc., Melville, NY). All egg images were imported into an image processing software (Image J v.1.35, see http://rsb.info.nih.gov/ij/) and a digital measuring tool was used to make calculations of each egg's longest axis. All egg calculations were measured to the nearest $0.1 \mathrm{~mm}$ (then converted to $\mu \mathrm{m}$ ) and values for each sample were averaged $( \pm \mathrm{se})$. Egg volumes were then calculated using the formula: $V=4 / 3 *(\pi$ $r^{3}$ ), where $\mathrm{r}$ is the radius for spheroid-shaped embryos (see Garcla-Guerrero \& Hendrickx, 2004).

\section{Data analysis}

Analysis of variance (ANOVA) was used to investigate potential differences in egg protein and lipid content between the three thermal regimes (fixed factor 1) at each of the five sampling intervals (fixed factor 2). A 3x5 full factorial design was used and analyzed as a split-plot (SP) ANOVA (whole-plot $=$ temperature, sub-plot $=$ month, $\left.d f_{\text {total }}=15\right)$ using a PROC MIXED model in SAS v. 9.3 (SAS Institute Inc., Cary, NC). For all ANOVA models, we tested the assumptions of normality, independence, and homogeneity of variance and used a Kuskal Wallis H-test where these assumptions were not supported. Differences between groups were compared using the 
214 PDIFF function in SAS. Regression analyses were carried out using JMP v. 9.3 (SAS Institute

215 Inc., Cary, NC) statistical software. All means are expressed \pm se.

216

217 RESULTS

218

219 Water temperatures

220 Seawater temperatures over the entire course of this study (October-May) averaged $7.1 \pm 0.24^{\circ} \mathrm{C}$

$221($ range $=2.1-11.2)$ for inshore laboratory trials, compared with $6.0 \pm 0.19^{\circ} \mathrm{C}($ range $=2.8-10.1)$

222 for the offshore thermal regime, and $16.2 \pm 0.21^{\circ} \mathrm{C}$ for the constant treatment tank (Fig. 1). There

223 was an overall significant difference in water temperatures between the constant tank treatment

224 and both inshore and offshore ones (ANOVA, Kruskal-Wallis H-Test; $F_{2,7}=10.32, P<0.0001$;

225 Fig. 1) but not between inshore and offshore. It is worth noting that temperatures in the inshore

226 and offshore treatments converged quickly at the outset of the experiment and diverged markedly

227 starting only in early April (Fig. 1). Thus, it is not surprising that there was no difference in

228 embryo development between inshore and offshore treatments, at least until the March sampling,

229 however inshore temperatures were warmer in April and May compared with offshore locations

$230(P<0.05)$.

231

232 Lipid and protein content

233 Both total egg lipid and protein levels from inshore and offshore thermal regimes differed from

234 their constant temperature counterpart (SPANOVA; $P=0.0002$, Fig. 2). Likewise, the interactive

235 effect of temperature and month was significant for both lipid $\left(F_{7,44}=2.27, P<0.045\right)$ and

236 protein levels $\left(F_{7,44}=46.5, P<0.0001\right.$, Table 1$)$. Overall egg lipid values showed a decrease 
237 over time (equation: lipids $=381.76-55.00 *$ month, $r_{a d j}^{2}=0.85, P<0.0001$; Fig. 2), falling most

238 dramatically early in the fall (-16.8\% inshore, $-21.4 \%$ offshore, $-24.8 \%$ constant $)$ and late spring

$239(-63.7 \%$ inshore, $-59.0 \%$ offshore). By contrast, total lobster egg protein values increased over

240 the same time-frame (equation: proteins $=-35.53+69.11 *$ month, $r^{2}{ }_{a d j}=0.63, P<0.0001$; Fig.

241 2), and exhibited the largest increases in the fall (60.4\% inshore, $57.7 \%$ offshore, $66.5 \%$

242 constant) and spring (30.1\% inshore, 37.1\% offshore).

243

244

245

246

247

248

249

250

251

252

253

254

255

256

257

258

259

260

\section{Egg volumes}

Overall, there was a significant increase in egg volume over time for all eggs over all treatments $\left(r_{a d j}^{2}=0.413, P<0.001\right)$. However, there were no significant changes with respect to egg volume by treatment $(F=0.73, d f=2, P=0.513)$ (overall means: inshore $=3226 \pm 163 \mu \mathrm{m}^{3}$, offshore $=3254 \pm 167 \mu \mathrm{m}^{3}$, constant $=3476 \pm 152 \mu \mathrm{m}^{3}$ ), even though there were differences from month-to-month $(F=2.25, d f=3, P<0.001$; Fig. 3$)$.

DISCUSSION

Our main goal was to document the changes in lipids and proteins in lobster eggs as they developed during exposure to three different thermal regimes in the laboratory. In general, we found that the trends during embryogenesis in H. americanus were typical of other decapods: lipid reserves were catabolized while proteins were utilized to make tissues (Holland, 1978; Sasaki, McDowell Capuzzo \& Biesiot, 1986; Jacobs, Biesiot, Perry \& Trigg, 2003; Brillon, Lambert \& Dodson, 2005). In tandem with these patterns, eggs were also shown to increase in diameter. Not surprisingly, lobster eggs exposed to an elevated, constant temperature developed 
261 faster and thus used up more of their energy reserves (lipids) sooner than eggs subjected to

262 natural thermal regimes, which included decreases in water temperatures from November to

263 March.

264

265 In this study we did not obtain data for biochemical changes that occurred in eggs that were

266 approaching hatch ( 30 days prior), nor the effects of the different thermal regimes on larval

267 survivorship or condition but a complementary study did find differences in time of hatch

268 (Goldstein \& Watson, 2015a). This may have been why there were no apparent biochemical

269 differences in lobster eggs between inshore and offshore temperature treatments, even though

270 inshore temperatures increased more rapidly in the spring. Previous studies have shown that

271 large changes in egg yolk lipids and protein levels occur within the last few weeks of

272 development (Sibert, Ouellet \& Brethes, 2004), and we reported that eggs exposed to inshore

273 thermal regimes hatch sooner than those that experience offshore conditions (Goldstein \&

274 Watson, 2015a,b). Therefore, we expect there would have been difference in egg biochemistry if

275 we had been able to obtain samples just before hatching in the spring.

276

277 Other studies have shown the influence of different thermal exposures on larval condition

278 (Sasaki, McDowell Capuzzo \& Biesiot, 1986; Ouellet \& Plante, 2004), and it was very clear that

279 significant changes to lobster egg biochemistry are apparent in the first two months of

280 development (this study) as well as leading up to the month before hatching (Sasaki, McDowell

281 Capuzzo \& Biesiot, 1986). The effect of temperature on metabolic and developmental rates is

282 expressed through changes in the consumption rates of metabolic reserves that are affected by

283 changing temperatures (Sasaki, McDowell Capuzzo \& Biesiot, 1986). Thus, the seasonal aspects 
284 of fluctuating temperature impact the rates and course of development in lobster eggs. It is

285 suggested that fluctuating seasonal temperatures help to accelerate egg development during some

286 time frames while depressing it at others, providing temporal windows where hatching generally

287 takes place (Helluy \& Beltz, 1991; Waddy \& Aiken 1995; Goldstein \& Watson, 2015b).

288

289 Seasonal movements by ovigerous lobsters may have evolved then to expose their eggs to the 290 most suitable available water temperatures for development, or to ensure that females reside in

291 ideal locations when the eggs hatch to increase larval survival (Gendron \& Ouellet, 2009;

292 Goldstein and Watson 2015b). This certainly seems to be the case in movements of late-stage

293 ovigerous Caribbean spiny lobster (Panulirus argus) where these animals made homing

294 excursions from their dens on the reef to the reef edge to release their larvae (Bertelsen \&

295 Hornbeck 2009). It is also possible that, by moving offshore, egg incubation time is actually

296 slowed down, which might both conserve internal egg resources and delay hatch until

297 environmental conditions are optimal in the spring. Seasonally changing temperatures, including

298 a refractory period of cold seawater temperatures $\left(<5^{\circ} \mathrm{C}\right)$ that elicits a stasis in eggs are

299 important to conserving egg resources for more rapid increases in temperature $\left(>10^{\circ} \mathrm{C}\right)$ that 300 typically occur later on (Waddy \& Aiken, 1995).

301

302 Lipids and proteins

303 Many studies conducted on crustacean eggs show that lipids are the major energy reserve 304 (Holland, 1978; Fraser, 1989; Clarke, Brown \& Holmes, 1990; Heras, Gonzales-Baro \& 305 Pollero, 2000). Although egg yolk lipids were consumed at disparate rates in our thermal 306 treatments and throughout all months, lipids were consumed much more modestly in winter (Fig. 
307 2). This pattern is seen consistently in other crustaceans as well. For example, the egg lipid

308 content of fiddler crab (Uca rapax) decreases significantly (78.4\%) through embryogenesis,

309 confirming that lipids constitute an important energy source for embryonic development

310 (Figueiredo, Penha-Lopes, Anto, Narciso \& Lin, 2008). In addition, lipids are also used as

311 structural components of cell membranes that are being formed as they grow (Rosa \& Nunes,

312 2003). Thus, the catabolism of lipids is a classic feature of crustacean eggs and many other

313 crustaceans produce eggs with large lipid reserves that are used throughout embryogenesis

314 (Rosa, Calado, Narcisco \& Nunes, 2007). Lipid depletion rates are directly related to incubation

315 temperature, and it has been observed in other crustaceans that the energy consumption per day

316 slightly intensified 3 or 4 days before hatching, which could be related to a higher energy

317 production need at this time (Heras, Gonzales-Baro \& Pollero, 2000). Yolk lipids tend to

318 become catabolized first followed by yolk proteins. These ratios change and can be used to

319 estimate the cost of egg development at differing temperatures (Sasaki, McDowell-Capuzzo \&

320 Biesiot, 1986). In the field, lipid profiles (e.g., fatty acids) have been used to identify offshore

321 from inshore lobster eggs (Castell, Boston, Miller \& Kenchington, 1995); therefore, it is possible

322 that these constituents are utilized differently across different geographic regions that correspond

323 to disparate thermal regimes.

325 For proteins, the consumption rate during embryogenesis may increase as temperature rises

326 (Conceicao, Ozorio, Suurd \& Verreth, 1998). Proteins both function as building blocks for

327 tissues and as a source of energy, when needed (Schmidt-Nielsen 1991). At elevated

328 temperatures (constant), increases in protein levels were detected and, at these elevated

329 temperatures, tissue synthesis tends to be inefficient and more protein might be used for energy 
330 instead (e.g., Garcia-Guerrero, Racotta \& Villareal, 2003; García-Echauri \& Jeffs, 2018).

331 Therefore, the duration and rates of differing thermal profiles would most certainly affect these

332 biochemical changes and allocations of resource components over time. How this translates to

333 larval survivorship remains poorly understood. However, Sasaki, McDowell Capuzzo \& Biesiot

334 (1986) showed that up until Stage IV (i.e., transitionary postlarval stage), lobsters depended, in-

335 part, upon stored lipids and that proper temperature synchronization in these residual lipids

336 maybe favorable to settlement processes.

\section{Egg volume}

339 Increases in egg volume are primarily due to water uptake by the embryo as well as from the

340 retention of metabolic water resulting from respiration (Pandian, 1970; Petersen \& Anger,

341 1997). The associated osmotic changes that ensue during egg development can be an important

342 component to hatching and have also been implicated in mechanically aiding the breakage of the

343 chorion near the time of hatch (Pandian, 1970). Slight changes in lobster egg volume have been

344 previously explained as a function of a plastic response to variations in salinity (Charmantier \&

345 Aiken, 1987), and for later eggs, a consequence of physiological factors during development

346 (Pinheiro \& Hattori, 2003). In these instances, the movements or residency of lobsters in certain

347 locations where seawater salinities can vary dramatically during certain times of the year (e.g.,

348 estuaries; Watson, Vetrovs \& Howell, 1999) may have an impact on aspects of development or

349 hatch, especially near the latter part of egg development (Charmantier \& Aiken, 1987).

350

351

352

Peer) reviewing PDF | (2018:02:25864:2:1:NEW 25 Mar 2019) 


\section{Female size and condition}

354 In this study we did not specifically address the influence of maternal size or nutritional

355

356

357

358

359

360

361

362

363

364

365

366

367

condition on egg quality in H. americanus. However, other related studies have showed that caloric energy content per egg increases with female size (Attard \& Hudon, 1987). Sibert,

Ouellet \& Brethes (2004) described this relationship by creating a growth index model for egg development and found that larger eggs used yolk lipids more efficiently and sustained faster embryonic growth compared with smaller eggs. An effect of female size on egg reserve allocation has been reported in other decapods including snow crab (Chionoecetes opilio), giant crab (Pseudocarcius gigas), and lobster (Homarus americanus) (Attard \& Hudon, 1987; SainteMarie, 1993; Gardner, 2001). In lobsters it has been postulated that the effect of female size may mean that larger females make a greater contribution towards egg reserves (Attard \& Hudon, 1987). However, the added effect of temperature on egg quality may, in some cases override this effect and maternal nutrition may also modulate egg quality (Goldstein \& Shields, 2018). The lecithotrophic nature of lobster eggs is determined largely through the sequestering of maternal nutrients throughout the processes of primary and secondary vitellogenesis during oocyte formation, the latter of which is highly dependent on the female's organic energy reserves (e.g., lipoprotein; Dehn, Aiken \& Waddy, 1983).

\section{CONCLUSIONS}

Although the changes in biochemical components (lipids and proteins) in developing lobster eggs were not significantly different from inshore and offshore thermal regimes, the potential exits for variations in the energetics of embryogenesis influenced by the seasonal movements of 
378 some lobsters to and from these two disparate locations over the entire course of egg

379 development from egg extrusion to hatch. Because we did not see differences, in egg

380 biochemistry, inshore eggs hatched sooner even though the protein and lipid levels were the

381 same as offshore eggs. As seasonal thermal cycles fluctuate or potentially shift (i.e., climate

382 change), the timing of egg hatch and associated egg quality may modulate biochemical changes

383 to lobster eggs and have implications for hatch, larval energetics, and ultimately, hatch-to-

384 recruitment dynamics for this important fishery.

385

386

387

388

389

390

391

392

393

394

395

396

397

398

399

400

401

402

403

\section{ACKNOWLEDGEMENTS}

A special thanks to Nancy Whitehouse of the UNH Dairy Nutritional Research Center whose expertise and advice on biochemical analyses and statistics were very helpful to the completion of this project in addition to the use and training of diagnostic lab equipment. Project interns, Sarah Havener, May Grose, and Michelle Provencier, were also very helpful with many aspects of this study and their help is much appreciated. Nate Rennels and Noel Carlson of the UNH Coastal Marine Lab for their help in maintaining lobsters and the seawater system. A special appreciation to NH lobstermen Alan Vangile (F/V Special K) and Michael Pawluk (F/V Gretchen D) for the boat hours to trap and collect egg-bearing lobsters for this study. We also thank K. Liversage and one anonymous for constructive recommendations for improving this manuscript. 
404

405

406

407

408

409

410

411

412

413

414

415

416

417

418

419

420

421

422

423

424

425

426

427

428

429

430

431

432

433

434

435

436

437

438

439

440

441

442

443

444

445

446

\section{REFERENCES}

Aiken DE, Waddy SL. 1980. Reproductive Biology. In: Cobb JS, Phillips BF, eds. The Biology and Management of Lobsters. New York: Academic Press. 275-276.

Amsler MO, George RY. 1984. Seasonal variation in the biochemical composition of the embryos of Callinectes sapidus. Rathbun. Journal of Crustacean Biology 4:546-553.

Atlantic States Marine Fisheries Commission (ASMFC). 2015. Stock Assessment Report NA10NMF4740016. 493p.

Attard J, Hudon C. 1987. Embryonic development and energetic investment in egg production in relation to size of female lobster (Homarus americanus). Canadian Journal of Fisheries and Aquatic Sciences 44:1157-1163.

Bertelsen RD, Hornbeck J. 2009. Using acoustic tagging to determine adult spiny lobster (Panulirus argus) movement patterns in the Western Sambo Ecological Reserve (Florida, United States). New Zealand Journal of Marine and Freshwater Research 43:35-46.

Bligh EG, Dyer WJ. 1959. A rapid method of total lipid extraction and purification. Canadian Journal of Biochemistry and Physiology 37:911-917.

Brillon S, Lambert Y, Dodson J. 2005. Egg survival, embryonic development, and larval characteristics of northern shrimp (Pandalus borealis) females subject to different temperature and feeding conditions. Marine Biology 147:895-911.

Campbell A, Stasko AB. 1986. Movements of lobsters (Homarus americanus) tagged in the Bay of Fundy, Canada. Marine Biology 92:393-404.

Castell JD, Boston LD, Miller RJ, Kenchington T. 1995. The potential identification of the geographic origin of lobster eggs from various wild stocks based on fatty acid composition. Canadian Journal of Fisheries and Aquatic Sciences 52:1135-1140.

Charmantier G, Aiken DE. 1987. Osmotic regulation in late embryos and prelarvae of the American lobster Homarus americanus H. Milne-Edwards 1837 (Crustacea, Decapoda). Journal of Experimental Marine Biology and Ecology 109:101-108.

Clarke A, Brown J, Holmes L. 1990. The biochemical composition of eggs from Macrobrachium rosenbergii in relation to embryonic development. Comparative Biochemistry and Physiology 96(B):505-511. 
447

448

449

450

451

452

453

454

455

456

457

458

459

460

461

462

463

464

465

466

467

468

469

470

471

472

473

474

475

476

477

478

479

480

481

482

483

484

485

486

487

488

489

Conceicao L, Ozorio R, Suurd E, Verreth J. 1998. Amino acid profile and amino acid utlilization in larval African catfish Clarias gariepinus, effects of ontogeny and temperature. Fish Physiology and Biochemistry 19:43-57.

Cooper R, Uzmann J. 1980. Ecology of Juvenile and Adult Homarus. In: Cobb JS, Phillips BF, eds. The Biology and Management of Lobsters. New York: Academic Press, 97-142.

Cowan DF, Watson WH III, Solow AR, Mountcastle AM. 2007. Thermal histories of brooding lobsters, Homarus americanus, in the Gulf of Maine. Journal of Marine Biology 179:70-78.

Dehn PF, Aiken DE, Waddy SL. 1983. Aspects of vitellogenesis in the lobster Homarus americanus. Canadian Technical Report of Fisheries and Aquatic Sciences 161:1-28.

Figueiredo J, Penha-Lopes G, Anto J, Narciso L, Lin J. 2008. Potential fertility and egg development (volume, water, lipid, and fatty acid content) through embryogenesis of $U c a$ rapax (Decapoda: Brachyura: Ocypodidae). Journal of Crustacean Biology 28:528-533.

Fogarty MJ. 1995. Populations, Fisheries, and Management. In: Factor JR, ed. Biology of the lobster Homarus americanus. San Diego: Academic Press, 111-137.

Fraser A. 1989. Triacylglicerol content as a condition index for fish, bivalve and crustacean larvae. Canadian Journal of Fisheries and Aquatic Science 46:1868-1872.

Garcia-Guerrero M, Racotta I, Villareal H. 2003. Effect of temperature on lipids, proteins, and carbohydrates levels during development from egg extrusion to juvenile stage of Cherax quadricarinatus (Decapoda: Parastacidae). Comparative Biochemistry and Physiology Part A 135:147-154.

Garcia-Guerrero M, Hendrickx ME. 2004. Embryology of decapod crustaceans I. Embryonic development of the mangrove crabs Goniopsis pulchra and Aratus pisonii (Decapoda: Brachyura). Journal of Crustacean Biology 24:666-672.

García-Echauri LL, Jeffs A. 2018. Swimming energetics of the postlarvae of the spiny lobster Jasus edwardsii in New Zealand. Bulletin of Marine Science 94:821-833.

Gardner C. 2001. Composition of eggs in relation to embryonic development and female size in giant crabs (Pseudocarcinus gigas Lamarck). Marine and Freshwater Research 52:333338.

Gendron L., Ouellet P. 2009. Egg development trajectories of early and late-spawner lobsters (Homarus americanus) in the Magdalen Islands, Quebec. Journal of Crustacean Biology 29:356-363.

Peer) reviewing PDF | (2018:02:25864:2:1:NEW 25 Mar 2019) 
490

491

492

493

494

495

496

497

498

499

500

501

502

503

504

505

506

507

508

509

510

511

512

513

514

515

516

517

518

519

520

521

522

523

524

525

526

527

528

529

530

531

532

533
Giménez L. 2006. Phenotypic links in complex life cycles: conclusions from studies with decapod crustaceans. Integrative and Comparative Biology 46:615-622.

Goldstein JS. 2012. The impact of seasonal movements by ovigerous American lobsters (Homarus americanus) on egg development and larval release. Ph.D. dissertation, University of New Hampshire, Durham, NH.

Goldstein JS, Watson WH III. 2015a. Quantifying the influence of natural inshore and offshore thermal regimes on egg development in the North American lobster, Homarus americanus. Biological Bulletin 228:1-12.

Goldstein JS, Watson WH III. 2015b. Seasonal movements of American lobsters in southern Gulf of Maine coastal waters: Patterns, environmental triggers, and implications for larval release. Marine Ecology Progress Series 524:197-211.

Goldstein JS, Shields JD. 2018. Bait-subsidized diets and their effects on ovigerous North American lobsters (Homarus americanus). Aquaculture International. doi 10.1007/s10499-018-0285-8.

Helluy S, Beltz BS. 1991. Embryonic development of the American lobster Homarus americanus: Quantitative staging and characterization of an embryonic molt cycle. Biological Bulletin 180:355-371.

Heras H, Gonzales-Baro M, Pollero R. 2000. Lipid and fatty acid composition and energy portioning during the embryo development in the shrimp Macrobrachium borellii. Lipids 35:645-651.

Holland D. 1978. Lipid reserves and energy metabolism in the larvae of benthic marine invertebrates. In: D. C. Malins (Ed.). Biochemical and Biophysical Perspectives in Marine Biology. Academic Press, Seattle, Washington, 85-123.

Jacobs JR, Biesiot PM, Perry HM, Trigg C. 2003. Biochemical composition of embryonic crabs Callinectes sapidus Rathbun 1896 (Crustacea: Decapoda) from the Gulf of Mexico. Bulletin of Marine Science 72:311-324.

Jaeckle WB. 1995. Variation in the size, energy content and biochemical composition of invertebrate eggs: correlates to the mode of larval development. In: McEdward L, ed. Ecology of Marine Invertebrate Larvae. Boca Raton: CRC Press, 49-77.

Johnson KJ, Goldstein JS, Watson WH III. 2011. Two methods for determining the fertility status of early-stage American lobster, Homarus americanus, eggs. Journal of Crustacean Biology 31:693-700. 
534

535

536

537

538

539

540

541

542

543

544

545

546

547

548

549

550

551

552

553

554

555

556

557

558

559

560

561

562

563

564

565

566

567

568

569

570

571

572

573

574

575

576

577

578

579

Lawton P, Lavalli KL. 1995. Postlarval, juvenile, adolescent, and adult ecology. In: Factor JR, ed. Biology of the lobster Homarus americanus. San Diego: Academic Press, 47-81.

Lowry OH, Rosebrough NJ, Lewis Farr A, Randall RJ. 1951. Protein measurement with the folin phenol reagent. Journal of Biological Chemistry 193:265-274.

MacKenzie BR. 1988. Assessment of temperature effect on interrelationships between stage durations, mortality, and growth in laboratory-reared Homarus americanus Milne Edwards larvae. Journal of Experimental Marine Biology and Ecology 116:87-98.

Manush SM, Pal K, Das T, Mukherjee S. 2006. The influence of temperatures ranging from 25 to $36 \mathrm{C}$ on developmental rates, morphogenesis and survival of freshwater prawn (Macrobrachium rosenbergii) embryos. Aquaculture 256:529-536.

Nelson K, Hedgecock D, Borgeson W. 1988. Factors influencing egg extrusion in the American lobster (Homarus americanus). Canadian Journal of Fisheries and Aquatic Sciences 45:797-804.

Ouellet P, Plante F. 2004. An investigation of the sources of variability in American lobster (Homarus americanus) eggs and larvae: Female size and reproductive status, and interannual and interpopulation comparisons. Journal of Crustacean Biology 24:481-495.

Pandian TJ. 1970. Yolk utilization and hatching in the Canadian lobster Homarus americanus. Marine Biology 7:249-254.

Perkins H. 1972. Developmental rates at various temperatures of embryos of the northern lobster (Homarus americanus Milne Edwards). Fisheries Bulletin 70:95-99.

Petersen S, Anger K. 1997. Chemical and physiological changes during the embryonic development of the spider crab Hyas arenus (Decapoda: Majidae). Comparative Biochemistry and Physiology 117B:299-306.

Pinheiro M, Hattori G. 2003. Embryology of the mangrove crab Ucides cordatus (Brachyura: Ocypodidae). Journal of Crustacean Biology 23:729-737.

Racotta IS, Ibarra M. 2003. Shrimp larval quality in relation to broodstock condition. Aquaculture 227:107-130.

Rosa R, Nunes ML. 2003. Tissue biochemical composition in relation to the reproductive cycle of deep-sea decapod Aristeus antennatus in the south Portugese coast. Journal of the Marine Biological Association of the United Kingdom 83:963-970.

Rosa R, Calado L, Narciso L, Nunes ML. 2007. Embryogenesis of decapod crustaceans with different life history traits, feeding ecologies, and habitats: a fatty acid approach. Marine Biology 151:935-947. 
580

581

582

583

584

585

586

587

588

589

590

591

592

593

594

595

596

597

598

599

600

601

602

603

604

605

606

607

608

Sainte-Marie B. 1993. Reproductive cycle and fecundity of primiparous and multiparous female snow crab, Chionoecetes opilio, in the northwest Gulf of St. Lawrence. Canadian Journal of Fisheries and Aquatic Sciences 50:2147-2156.

Sasaki GC, McDowell Capuzzo J, Biesiot P. 1986. Nutritional and bioenergetic considerations in the development of the American lobster Homarus americanus. Canadian Journal of Fisheries and Aquatic Sciences 43:2311-2319.

Schmidt-Nielsen K. 1991. Animal Physiology: Adaptation and Environment, $4^{\text {th }}$ Ed. Cambridge University Press. Cambridge, UK.

Sibert V, Ouellet P, Brethes J-C. 2004. Changes in yolk total proteins and lipid components and embryonic growth rates during lobster (Homarus americanus) egg development under a simulated temperature cycle. Marine Biology 144:1075-1086.

Talbot P, Helluy S. 1995. Reproduction and Embryonic Development. In: Factor JR, ed. Biology of the lobster Homarus americanus. San Diego: Academic Press, 177-216.

Templeman W. 1940. Embryonic development rates and egg laying of Canadian lobsters. Journal of the Fisheries Research Board of Canada 5:71-83.

Vance R. 1973. Reproductive strategies in marine benthic invertebrates. American Naturalist 107:339-352.

Waddy SL, Aiken DE. 1995. Temperature regulation of reproduction in female American lobsters (Homarus americanus). ICES Marine Science Symposia 199:54-60.

Watson WH III, Vetrovs A, Howell WH. 1999. Lobster movements in an estuary. Journal of Marine Biology 134:65-75. 


\section{Figure 1}

Average temperature profiles for three thermal treatments

Weekly temperature averages compiled for three thermal treatments: inshore, offshore, and constant) from October-June, 2006-2007. See Methods section for details. There was an overall significant difference in water temperatures between the constant tank treatment and both inshore and offshore ones (ANOVA, Kruskal-Wallis H-Test; $F_{2,7}=10.32, P<0.0001$ ) but not between inshore and offshore.

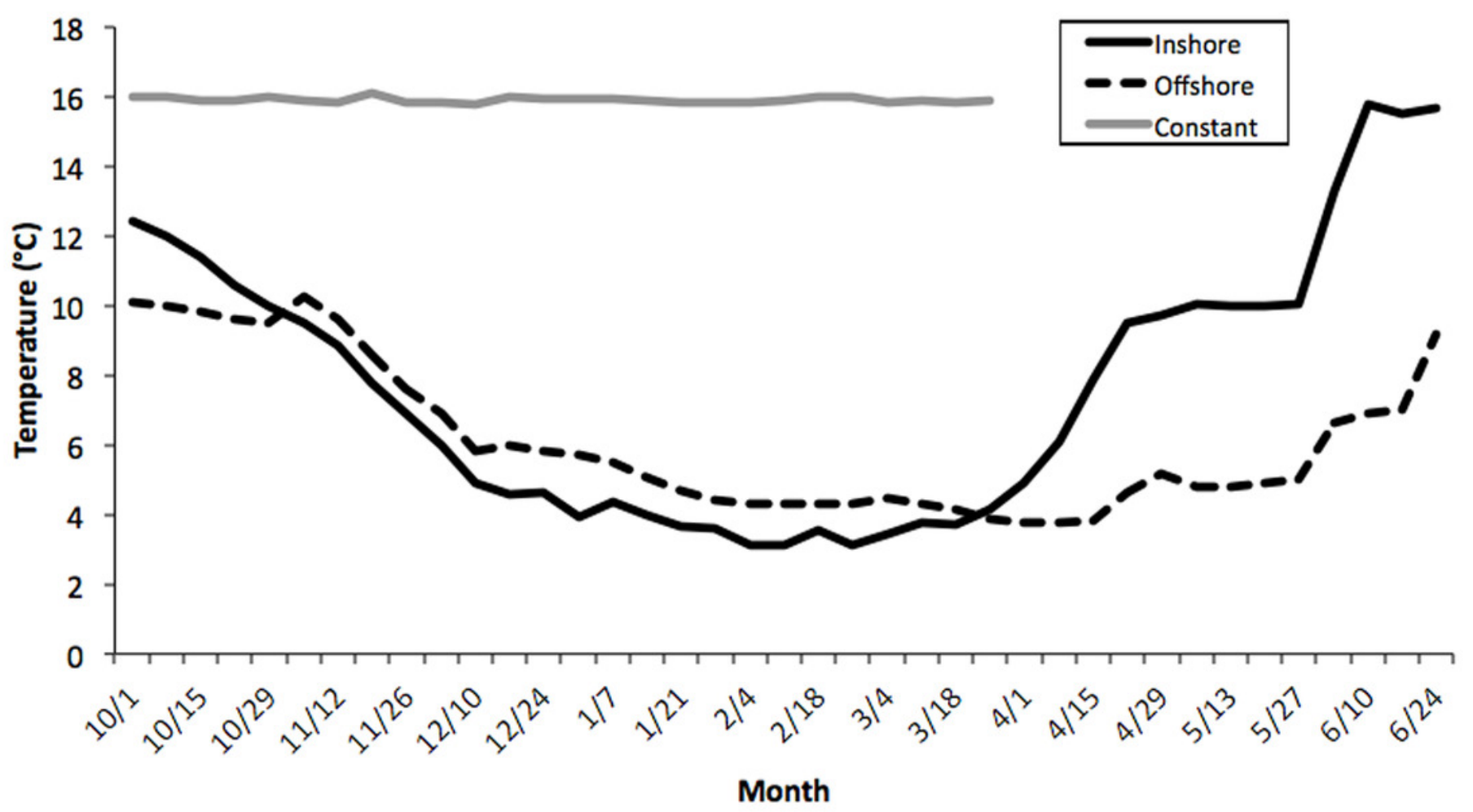


Figure 2 (on next page)

Changes in lobster egg lipids and proteins

(A) Change in lipids and (B) protein levels (means \pm se) over the course of seven months of egg development for all lobsters sampled ( $n=5 / \mathrm{trt})$. Posthoc differences $(P<0.001)$ between treatments denoted with an *. Lobsters exposed to inshore and offshore thermal treatments did not hatch their eggs until after May, unlike eggs from the constant treatment, where eggs hatched $(\mathrm{H})$ in April. 
A.

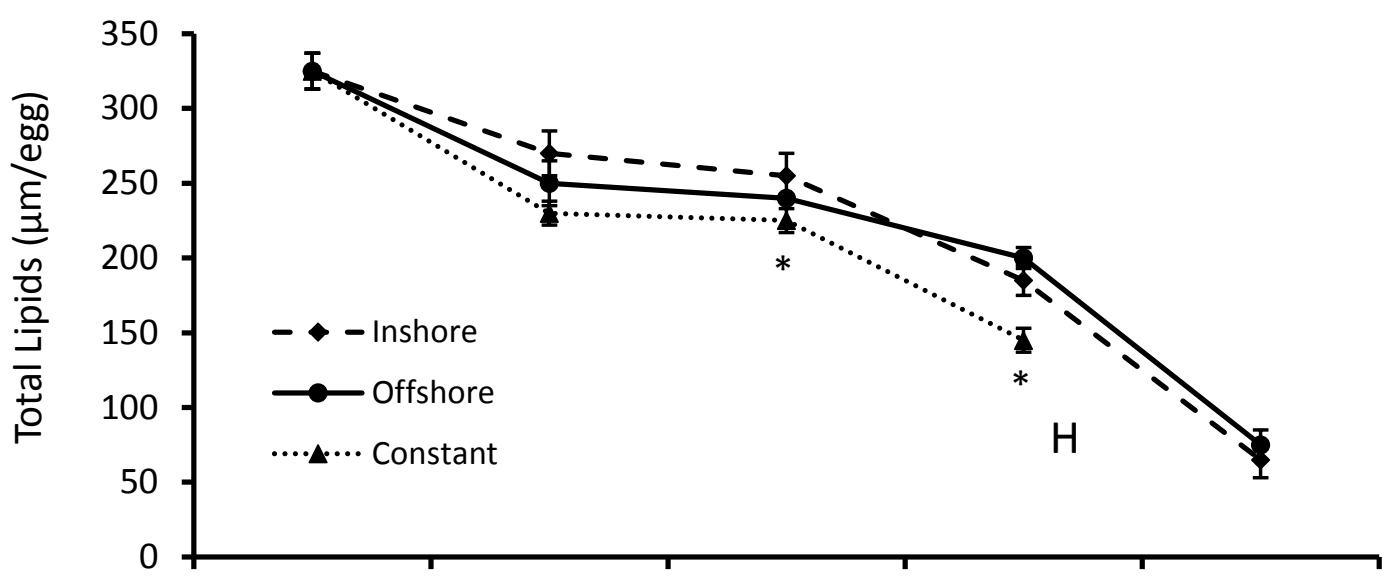

B.

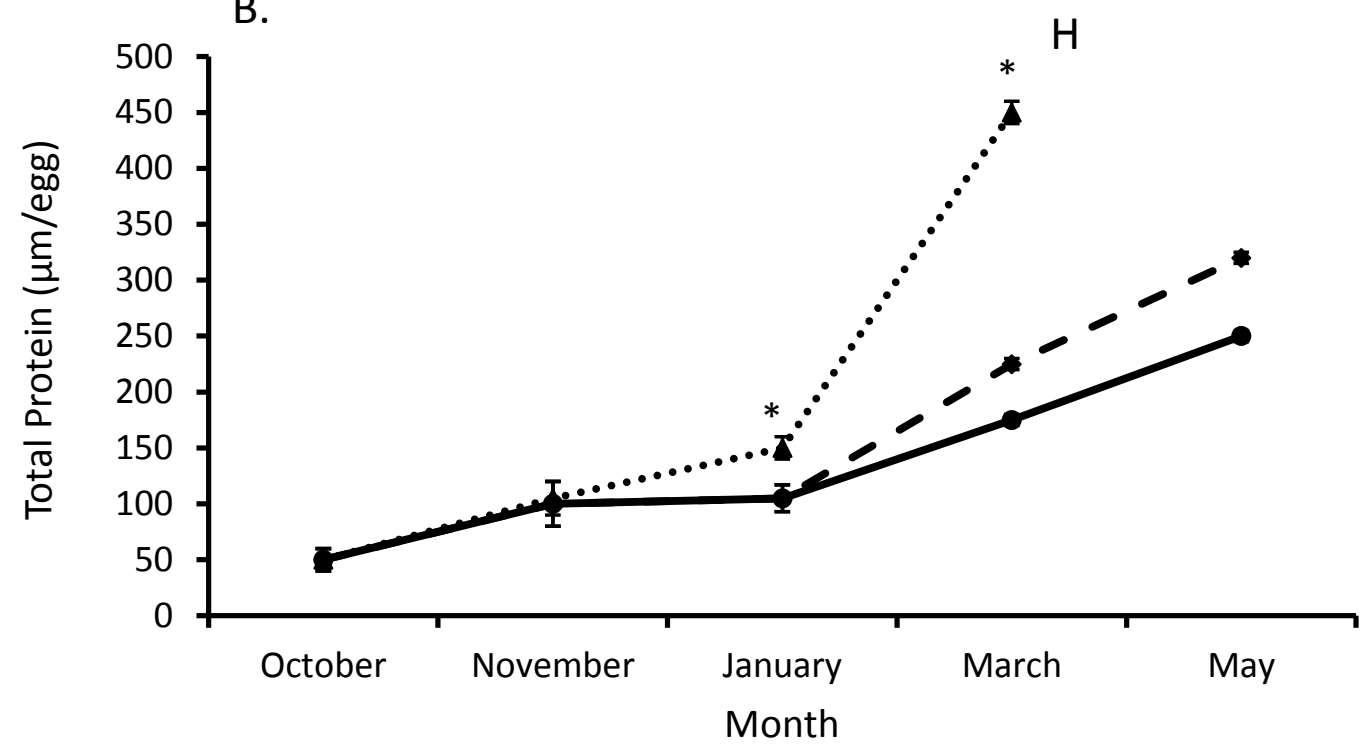




\section{Figure 3}

Changes in lobster egg volumes

A summary of means ( \pm se) for changes in lobster egg volumes (given in $\mu \mathrm{m}^{3}$ ) over a six month period. There were no significant differences in egg volume by treatment (Tukey's HSD; $q=2.40, P>0.05)$, but differences did exist from month-to-month $(F=2.25, d f=3, P$ $<0.001)$.

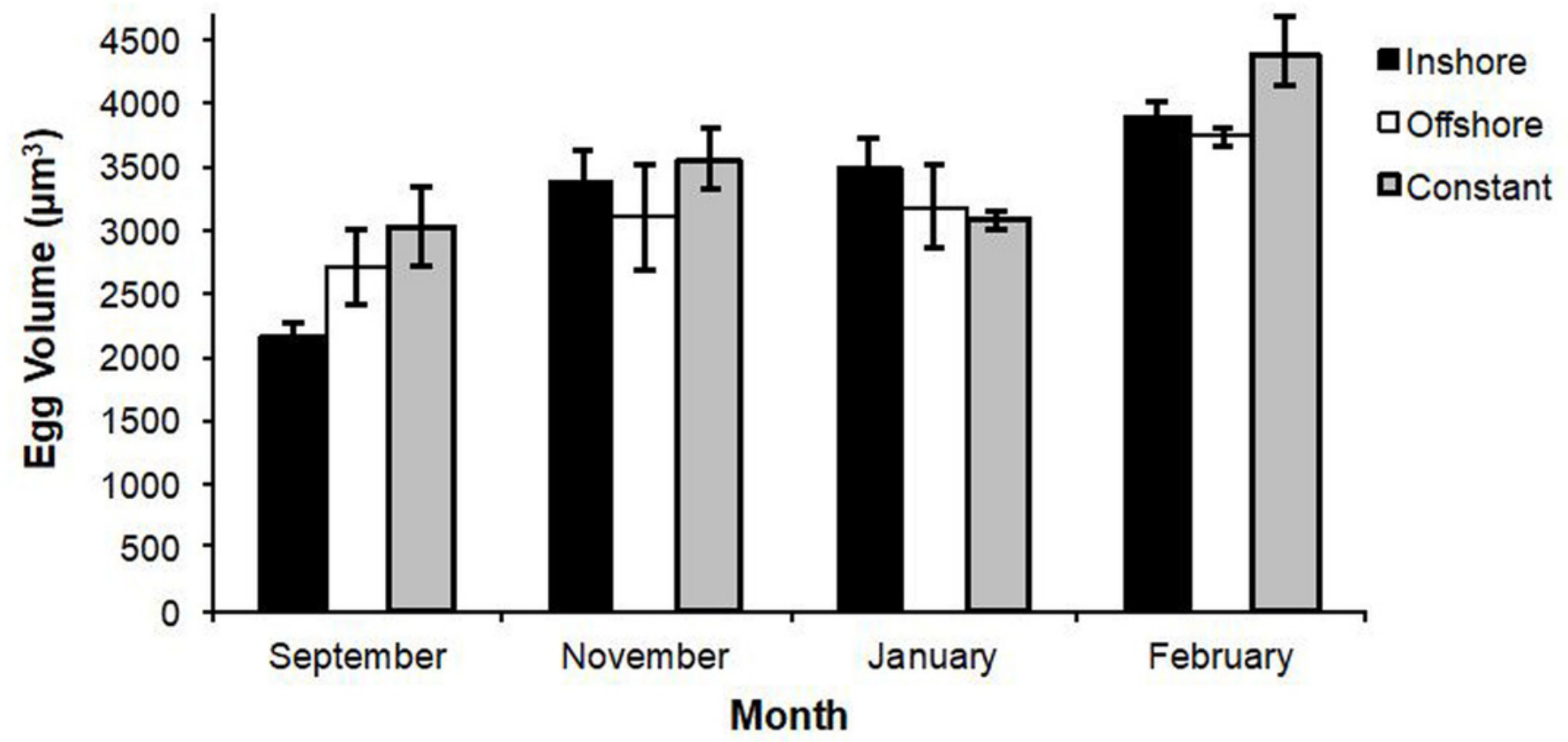




\section{Table $\mathbf{1}$ (on next page)}

Lipid and protein values with temperature

Pairwise comparisons ( $p$-values) between temperature treatment and month for both lipids and protein values. Boldface $P$-values $(<0.05)$ denote significant differences between temperatures for a specific month. 
1

2

3

4 Table 1

5

\begin{tabular}{cccccc}
\hline Treatment & October & November & January & March & May \\
\hline Inshore ${ }^{*}$ offshore & 0.85 & 0.30 & 0.21 & 0.25 & 0.24 \\
Inshore ${ }^{*}$ constant & 0.89 & $\mathbf{0 . 0 3}$ & $\mathbf{0 . 0 0 2}$ & $\mathbf{0 . 0 0 2}$ & - \\
Constant ${ }^{*}$ offshore & 0.72 & 0.22 & $\mathbf{0 . 0 4}$ & $<\mathbf{0 . 0 0 0 1}$ & - \\
\hline
\end{tabular}

6 